\title{
The problem of axonal injury in the brains of veterans with histories of blast exposure
}

\author{
Jiwon Ryu', Iren Horkayne-Szakaly², Leyan Xu', Olga Pletnikova', Francesco Leri ${ }^{5}$, Charles Eberhart ${ }^{1}$, \\ Juan C Troncoso ${ }^{1}$ and Vassilis E Koliatsos ${ }^{1,3,4^{*}}$
}

\begin{abstract}
Introduction: Blast injury to brain, a hundred-year old problem with poorly characterized neuropathology, has resurfaced as health concern in recent deployments in Iraq and Afghanistan. To characterize the neuropathology of blast injury, we examined the brains of veterans for the presence of amyloid precursor protein (APP)-positive axonal swellings typical of diffuse axonal injury (DAl) and compared them to healthy controls as well as controls with opiate overdose, anoxic-ischemic encephalopathy, and non-blast TBI (falls and motor vehicle crashes).

Results: In cases with blast history, we found APP (+) axonal abnormalities in several brain sites, especially the medial dorsal frontal white matter. In white matter, these abnormalities were featured primarily by clusters of axonal spheroids or varicosities in a honeycomb pattern with perivascular distribution. Axonal abnormalities colocalized with IBA1 $(+)$ reactive microglia and had an appearance that was distinct from classical DAl encountered in TBI due to motor vehicle crashes. Opiate overdose cases also showed APP (+) axonal abnormalities, but the intensity of these lesions was lower compared to cases with blast histories and there was no clear association of such lesions with microglial activation.
\end{abstract}

Conclusions: Our findings demonstrate that many cases with history of blast exposure are featured by APP (+) axonopathy that may be related to blast exposure, but an important role for opiate overdose, antemortem anoxia, and concurrent blunt TBI events in war theater or elsewhere cannot be discounted.

Keywords: Traumatic brain injury, Diffuse axonal injury, APP, Axon bulbs, Opiate, Microglia

\section{Introduction}

Blast injury to brain, the signature injury of recent conflicts in Iraq (Operation Iraqi Freedom; OIF) and Afghanistan (Operation Enduring Freedom; OEF), is a hundred-year old problem that began with the introduction of trinitrotoluene in artillery shells in WWI [1]. Based on recent Department of Defense estimates [2], there are presently upwards of 250,000 OEF/OIF veterans with traumatic brain injury (TBI) history, many of them due to blast, and the importance of understanding the long-term sequelae of blast TBI cannot be overestimated. Blast TBI is complex and incorporates the direct effects of overpressure wave (primary injury), the gunshot-like

\footnotetext{
* Correspondence: koliat@jhmi.edu

'Department of Pathology, Division of Neuropathology, Johns Hopkins University School of Medicine, Baltimore, MD 21205, USA

${ }^{3}$ Department of Neurology, Johns Hopkins University School of Medicine, Baltimore, MD 21205, USA

Full list of author information is available at the end of the article
}

effects of debris and shrapnel showering the head (secondary injury), the fall impact from translocation of the body by the overpressure wave (tertiary injury), as well as flash burns from the intense heat and asphyxiation or inhalation injuries [3]. Concurrent lesions to other organs leading to respiratory or heart failure or severe hemorrhage may contribute to brain hypoxia/ischemia. Factors that further complicate the long-term outcomes of blast injury are the complex dynamics of blast wave propagation, the mitigating or potentially enhancing effects of personal protective equipment [3], the number of blast exposure events [4,5], as well as the associated comorbidities of PTSD, chronic pain and substance abuse [6-8].

Despite the hundred-year long history of blast TBI and its significance for military medicine and beyond, its neuropathology has been very poorly characterized [9]. Part of the problem is lack of sufficient high-quality autopsy material, especially from long-term survivors of blast injuries. Recent reports from animal models of blast 
suggest the presence of axonal injury in select CNS tracts $[10,11]$, but the occurrence or significance of axonal injury in the brains of human subjects with blast exposure is still a matter of debate $[4,12]$.

Diffuse Axonal Injury (DAI) is a common event in human TBI, ranging from mild (concussive) to severe, including lethal, TBI [13-17]. DAI is a convention used for multifocal injury of long axons associated with impulse loading and encountered primarily in humans and other gyrencephalic animals [18]. DAI is featured by progressive axolemmal and axoskeletal alterations leading from axonal swellings (bulbs) to axotomy and the formation of retraction balls $[19,20]$. DAI was initially identified with silver degeneration methods [21]; however, because many neuronal proteins, including neurofilament proteins and amyloid precursor protein (APP) accumulate in damaged axons, immunohistochemistry (IHC) for these proteins has largely replaced silver methods in recent studies $[14,19,22-24]$. This paper directly documents the presence of APP (+) DAI in the brains of veterans with blast exposure history and raises important issues of interpretation and differential diagnosis.

\section{Materials and methods Subjects}

Subjects were veterans with prior history of blast $(n=5$; all males; ages 23-38, average 28; three of these subjects had died by opiate and/or alcohol overdose); controls with history of opiate overdose ( $n=6$; 2 males, 4 females; ages 18-48, average 25) or anoxic-ischemic encephalopathy ( $n=6$; 3 males, 3 females; ages $16-45$, average 28); TBI controls with history of motor vehicle crashes (MVC) or falls $(n=5$; all males; ages $18-51$, average 31$)$; and controls without history of TBI, opiate overdose or anoxic-ischemic encephalopathy $(n=7 ; 4$ males, 3 females; ages 21-70, average 36) (Table 1). Brains were provided through the Armed Forces Institute of Pathology (AFIP) autopsy service or the Johns Hopkins Brain Resource Center (BRC). Blast cases included in this study did not have, as far as we know, contusional injuries. Essential demographic and clinical data as well as main neuropathological findings are summarized in Table 1. In addition, we used cases with Alzheimer's disease and dementia pugilistica from the BRC collection as positive controls for phosphorylated tau IHC (see below).

\section{Preparation of tissues, histology and IHC}

Brains were immersion fixed in $10 \%$ formalin for two weeks at room temperature. Coronal tissue slabs were processed and embedded in paraffin and serial $10 \mu \mathrm{m}$ thick sections from standard blocks through frontal parasagittal cortex, anterior corpus callosum, hippocampus, thalamus, dorsolateral pons at the level of the superior cerebellar peduncle and cerebellar cortex were stained with hematoxylin and eosin, Cresyl violet, Masson's trichrome, and processed for the IHC detection of: amyloid precursor protein (APP) (using a monoclonal antibody against the amino-terminus of APP [clone 22C11; MAB348 from Millipore, Temecula, CA] concentrated 1:200) as a marker of abnormal axons; glial fibrillary acidic protein (using a rabbit monoclonal antibody against the C-terminal of GFAP [clone EP672Y; 04-1031 from Millipore] concentrated 1:500) as marker of astrocytes; ionized calcium- binding adaptor molecule 1 antibody (IBA1; a rabbit polyclonal antibody [CP290A from Biocare Medical LLC, Concord, CA] concentrated 1:300) as microglial marker; and mixed phosphorylated neurofilament epitopes (a mouse monoclonal antibody against phosphorylated neurofilament $\mathrm{H}$ and, to a limited extent, neurofilament M [SMI-310R; Covance, Emeryville, CA] concentrated 1:200) as generic axonal marker.

Sections through the frontal cortex and hippocampus from all blast cases were also processed for phosphorylated tau IHC with antibodies AT8, PHF1, and CP13 and the conformational tau antibody MC1. AT8 is directed against tau pS202 (MN1020; Thermo Scientific Inc., Rockford, IL); PHF1 is directed against tau pS396 and pS404; CP13 is directed against tau pS202 and pT205; and the conformational antibody $\mathrm{MC} 1$ is directed against the third microtubule binding domain of tau (amino acids 313 to 322 ) and recognizes the conformation formed by $\mathrm{N}$-terminus amino acid 7 to 9 and amino acids 313 to 322 in neurofibrillary tangles, but not fetal Alz-50reactive clone 1. Antibodies PHF1, CP13 and MC1 were provided by Dr. Peter Davies, Albert Einstein College of Medicine, Bronx, NY. All antibodies were used in 1:200 concentration. Normal IgG from the species of origin of the primary antibodies was used as negative control.

Immunoperoxidase IHC was performed essentially as described in Hedreen and Koliatsos (1994) [25] with some modifications. Paraffin sections were deparaffinized and rehydrated by incubation at $60^{\circ} \mathrm{C}$ for 30 minutes followed by sequential treatments with xylene, $100 \%$ and $95 \%$ ethanol. Endogenous peroxidase activity was blocked with hydrogen peroxide. Three percent (w/v) normal IgG in TBS including $0.1 \%$ Tween 20 solution was used for blocking and antibody incubation. The appropriate biotinylated goat anti-primary antibody IgGs in concentrations 1:250 to 1:400 were used as secondary antibodies. A standard avidin-biotin peroxidase reaction (PK-6100, Vector Lab. Inc., Burlingame, CA) followed by diaminobenzidine $(D A B)$ incubation were used to visualize immunoreactive epitopes. For double IHC of IBA1 or GFAP with APP, APP immunoreactivity was detected first as stated previously and IBA1 or GFAP immunoreactivity was detected by ImmPRESS-AP Anti-rabbit IgG 
Table 1 Demographic, clinical and neuropathological signatures of subjects included in this study

\begin{tabular}{|c|c|c|c|c|c|c|}
\hline Case & $\begin{array}{l}\text { Age/ } \\
\text { Gender }\end{array}$ & Cause of death & $\begin{array}{l}\text { Combat } \\
\text { history }\end{array}$ & Blast/TBI history & $\begin{array}{l}\text { Opiate overdose } \\
\text { history }\end{array}$ & $\begin{array}{l}\text { Anoxic-Ischemic } \\
\text { brain changes }\end{array}$ \\
\hline 1 & $38 \mathrm{M}$ & Multi-organ failure & Yes & Blast 2 mo PTD 1 & No & Purkinje Cell Degeneration \\
\hline 2 & $23 \mathrm{M}$ & GSW of head & Yes & Blast 11 mo PTD ${ }^{2}$ & No & None \\
\hline \multirow[t]{2}{*}{3} & \multirow[t]{2}{*}{$26 \mathrm{M}$} & \multirow[t]{2}{*}{ Methadone overdose } & \multirow[t]{2}{*}{ Yes } & Blast 1 yr PTD & \multirow[t]{2}{*}{ Yes } & \multirow[t]{2}{*}{ Purkinje Cell Degeneration } \\
\hline & & & & $\begin{array}{l}\text { Concussion due to } \\
\text { Assault } 2 \text { mo PTD }\end{array}$ & & \\
\hline \multirow[t]{2}{*}{4} & \multirow[t]{2}{*}{$28 \mathrm{M}$} & \multirow[t]{2}{*}{ Methadone overdose } & \multirow[t]{2}{*}{ Yes } & \multirow[t]{2}{*}{ Blast 4 yrs PTD ${ }^{4}$} & \multirow[t]{2}{*}{ Yes } & CA1 Cell Degeneration \\
\hline & & & & & & Purkinje Cell Degeneration \\
\hline 5 & $25 \mathrm{M}$ & Alcohol and Opiate overdose & Yes & Blast PTD unknown & Yes & Purkinje Cell Degeneration \\
\hline 6 & $20 \mathrm{M}$ & Methadone overdose & No & $\mathrm{No}^{5}$ & Yes & None \\
\hline \multirow[t]{2}{*}{7} & \multirow[t]{2}{*}{$24 \mathrm{M}$} & Opiate overdose & \multirow[t]{2}{*}{ No } & \multirow[t]{2}{*}{ No } & \multirow[t]{2}{*}{ Yes } & CA1 Cell Degeneration \\
\hline & & Acute brain swelling & & & & Purkinje Cell Degeneration \\
\hline \multirow[t]{4}{*}{8} & \multirow[t]{4}{*}{$48 \mathrm{~F}$} & \multirow{4}{*}{$\begin{array}{l}\text { Methadone overdose Acute hypoxic- } \\
\text { ischemic encephalopathy }<24 \text { h duration }\end{array}$} & \multirow[t]{4}{*}{ No } & \multirow[t]{4}{*}{ No } & \multirow[t]{4}{*}{ Yes } & CA1 Necrosis \\
\hline & & & & & & Purkinje Cell Necrosis \\
\hline & & & & & & Cortical Necrosis \\
\hline & & & & & & Basal Ganglia Infarct \\
\hline 9 & $38 \mathrm{~F}$ & $\begin{array}{l}\text { Methadone and cocaine overdose } \\
\text { Cerebral edema Early hypoxic-ischemic } \\
\text { encephalopathy } 12 \mathrm{~h} \text { duration }\end{array}$ & No & No & Yes & $\begin{array}{l}\text { CA1 Necrosis Neocortical and } \\
\text { Entorhinal Necrosis }\end{array}$ \\
\hline 10 & $32 \mathrm{~F}$ & $\begin{array}{l}\text { Opiate overdose Cerebral edema Hypoxic- } \\
\text { ischemic encephalopathy } 48 \text { h duration }\end{array}$ & No & No & Yes & $\begin{array}{l}\text { CA1 Necrosis Neocortical } \\
\text { Necrosis }\end{array}$ \\
\hline 11 & $18 \mathrm{~F}$ & Opiate and antidepressant overdose & No & No & Yes & N/A \\
\hline \multirow[t]{2}{*}{12} & \multirow[t]{2}{*}{$22 \mathrm{~F}$} & \multirow[t]{2}{*}{$\begin{array}{l}\text { Acute hypoxic-ischemic encephalopathy } \\
27 \text { d duration }\end{array}$} & No & No & No & $\begin{array}{l}\text { CA1 Necrosis Purkinje and Deep } \\
\text { Nuclei Cell Necrosis Cortical } \\
\text { Necrosis Basal Ganglia }\end{array}$ \\
\hline & & & & & & Cell Necrosis \\
\hline 13 & $26 \mathrm{M}$ & Cardiac arrhythmia & No & $\mathrm{No}^{6}$ & No & CA1 Cell Degeneration \\
\hline & & Acute hypoxic-ischemic encephalopathy & & & & Purkinje Cell Degeneration \\
\hline 14 & $19 \mathrm{M}$ & Hypoxic-ischemic encephalopathy & Yes & Blast $19 \mathrm{~d} \mathrm{PTD}^{7}$ & No & CA1 Degeneration \\
\hline & & & & & & Purkinje Cell Degeneration \\
\hline & & & & & & Cortical cell death \\
\hline & & & & & & Basal ganglia cell death \\
\hline 15 & $16 \mathrm{~F}$ & Hypoxic-ischemic encephalopathy & No & No & No & CA1 Necrosis \\
\hline & & Iger & & & & Purkinje Cell Necrosis \\
\hline & & & & & & Neocortical Necrosis \\
\hline & & & & & & Basal ganglia Necrosis \\
\hline 16 & $45 \mathrm{~F}$ & Hypoxic-ischemic encephalopathy & No & No & No & CA1 Necrosis \\
\hline & & $<24 \mathrm{~h}$ duration & & & & Purkinje Cell Necrosis \\
\hline & & & & & & Neocortical Necrosis \\
\hline 17 & $39 M$ & Hypoxic-ischemic encephalopathy & No & No & No & CA1 Necrosis \\
\hline & & A & & & & Purkinje Cell Necrosis \\
\hline & & & & & & Neocortical Necrosis \\
\hline & & & & & & Basal ganglia Necrosis \\
\hline 18 & $22 \mathrm{M}$ & Extensive traumatic brain injury & No & $\begin{array}{l}\text { TBI due to MVA } \\
12 \text { d PTD }^{8}\end{array}$ & No & Purkinje Cell Degeneration \\
\hline & & Brain hemorrhage & & & & \\
\hline
\end{tabular}


Table 1 Demographic, clinical and neuropathological signatures of subjects included in this study (Continued)

\begin{tabular}{|c|c|c|c|c|c|c|}
\hline \multirow[t]{2}{*}{19} & \multirow[t]{2}{*}{$21 \mathrm{M}$} & Intra cerebral hemorrhage & \multirow[t]{2}{*}{ No } & \multirow{2}{*}{$\begin{array}{l}\text { TBI due to Fall } 4 \mathrm{~d} \\
\text { PTD }^{9}\end{array}$} & \multirow[t]{2}{*}{ No } & \multirow{2}{*}{$\begin{array}{l}\text { CA1 Cell Degeneration } \\
\text { Purkinje Cell Degeneration }\end{array}$} \\
\hline & & Brain herniation & & & & \\
\hline 20 & $18 \mathrm{M}$ & Extensive TBI & No & $\begin{array}{l}\text { TBI due to MVA } 2 \mathrm{~d} \\
\text { PTD }\end{array}$ & No & N/A \\
\hline 21 & $42 \mathrm{M}$ & Extensive TBI & No & MVC 6 d PTD & No & N/A \\
\hline 22 & $51 \mathrm{M}$ & Extensive TBI & No & MVC 3 h PTD & No & $\mathrm{N} / \mathrm{A}$ \\
\hline 23 & $21 \mathrm{M}$ & $\begin{array}{l}\text { Sudden death Heavy lungs } \\
\text { Negative toxicology }\end{array}$ & No & No & No & None \\
\hline \multirow[t]{3}{*}{24} & \multirow[t]{3}{*}{$28 \mathrm{M}$} & Sudden death & \multirow[t]{3}{*}{ No } & \multirow[t]{3}{*}{ No } & \multirow[t]{3}{*}{ No } & \multirow[t]{3}{*}{ None } \\
\hline & & Normal autopsy & & & & \\
\hline & & Negative toxicology & & & & \\
\hline \multirow[t]{2}{*}{25} & \multirow[t]{2}{*}{$21 \mathrm{M}$} & Sudden death & \multirow[t]{2}{*}{ No } & \multirow[t]{2}{*}{ No } & \multirow[t]{2}{*}{ No } & CA1 Cell Degeneration \\
\hline & & Stenosis of the coronary ostia & & & & Purkinje Cell Degeneration \\
\hline \multirow[t]{3}{*}{26} & \multirow[t]{3}{*}{$26 \mathrm{~F}$} & Sudden death & \multirow[t]{3}{*}{ No } & \multirow[t]{3}{*}{ No } & \multirow[t]{3}{*}{ No } & CA1 and Cortical Cell \\
\hline & & Mitral valve prolapse & & & & Degeneration \\
\hline & & & & & & Purkinje Cell Degeneration \\
\hline \multirow[t]{2}{*}{27} & \multirow[t]{2}{*}{$70 F$} & Sudden death & \multirow[t]{2}{*}{ No } & \multirow[t]{2}{*}{ No } & \multirow[t]{2}{*}{ No } & CA1 Cell Degeneration \\
\hline & & Cardiac arrhythmia & & & & Purkinje Cell Degeneration \\
\hline 28 & $26 \mathrm{M}$ & Heart attack & No & No & No & None \\
\hline 29 & $48 \mathrm{~F}$ & Heart attack & No & No & No & None \\
\hline
\end{tabular}

${ }^{1}$ IED; Other clinical problems: Burns 45\% TBA; Blast lung; Lung inhalational injuries; Secondary bacterial and fungal infections, ${ }^{2}$ Multiple IED; Other clinical problems: PTSD, ${ }^{3}$ (IED) with noncontusional ejection $10 \mathrm{ft}$ past explosion Other clinical problems: PTSD; Cognitive disorder secondary to TBl; Alcohol abuse, ${ }^{4}$ Other clinical problems: Postconcussive syndrome; PTSD; Depression; Adjustment disorder, ${ }^{5}$ Other clinical problems: Adjustment disorder with depression and anxiety; Migraine headaches, ${ }^{6}$ Other clinical problems: Multiple substance abuses, including inhalants and alcohol, ${ }^{7}$ IED; Other clinical problems: Chest injury; Ruptured spleen; Cardiac arrest, ${ }^{8}$ Related clinical findings: Multiple skull fractures; right frontal and temporal lobe contusions, ${ }^{9}$ Related clinical findings: Skull fracture; Left frontal/temporal contusions; subdural hematoma, PTD: Prior to death, CA1: Cornu ammonis 1 area in hippocampus, GSW: Gunshot wound, IED: Improvised explosive device, PTSD: Post-traumatic stress disorder, TBI: Traumatic brain injury, MVA: Motor vehicle accident, TBA: Total body area.

(MP-5401) or a Vector blue alkaline phosphatase substrate kit (SK-5300), both from Vector Lab. In some cases, we also performed silver staining with a variation of the Gallyas procedure using NeuroSilver ${ }^{\mathrm{Tm}}$ Kit II (PK301A) from FD NeuroTechnologies (Ellicott City, MD).

\section{Counts of APP (+) axonal swellings in cases with blast histories or methadone overdose}

Because the vast majority of cases with blast histories had died of opiate overdose, the relationship between blast exposure and APP (+) axonal pathology was further studied by comparing between cases with blast histories and cases with opiate overdose prior to death. Axonal swellings were visualized and counted on APPimmunostained sections of the superior frontal and cingulate gyri. The parasagittal white matter in these areas was outlined on one representative coronal section per case of subjects exposed to blast $(n=4)$ and subjects who died from opiate overdose $(n=4)$. The magnitude of APP $(+)$ axonal pathology was measured with the areal fraction fractionator probe [26] using the Stereo Investigator software (MicrobrightField Inc., Williston, VT). The fractional area of APP (+) axonal swellings was generated per case and then combined in the blast and opiate overdose groups that were further compared using a student's t-test.

\section{Results}

APP (+) axonal abnormalities in subjects with blast history In all cases with history of blast exposure except one (Case 2 ), the most consistent finding was APP-immunoreactive axonal varicosities or spheroids in the medial (parasagittal) frontal white matter, primarily in the superior and middle frontal and cingulate gyri (Figure 1). These lesions clustered in circular or semi-circular formations at short distances (50-200 $\mu \mathrm{m})$ from blood vessels and frequently coalesced in irregularly shaped lattices forming honeycomb patterns (Figure 1a-b). Similar patterns were often seen in the white matter of the anterior and middle temporal lobe. No parietal lobe tissues were available for review. The one case with blast history that did not show APP (+) axonal abnormalities in medial frontal white matter or elsewhere in the brain (Case 2) had a history of exposure to multiple IEDs and died from gunshot wound to the head (Table 1).

In some cases with blast histories, groups of abnormally swollen APP (+) axons and axon bulbs were also encountered in the corpus callosum (Additional file 1: Figure S1 for Case 3 but also Figure 2 for Case 1), the 


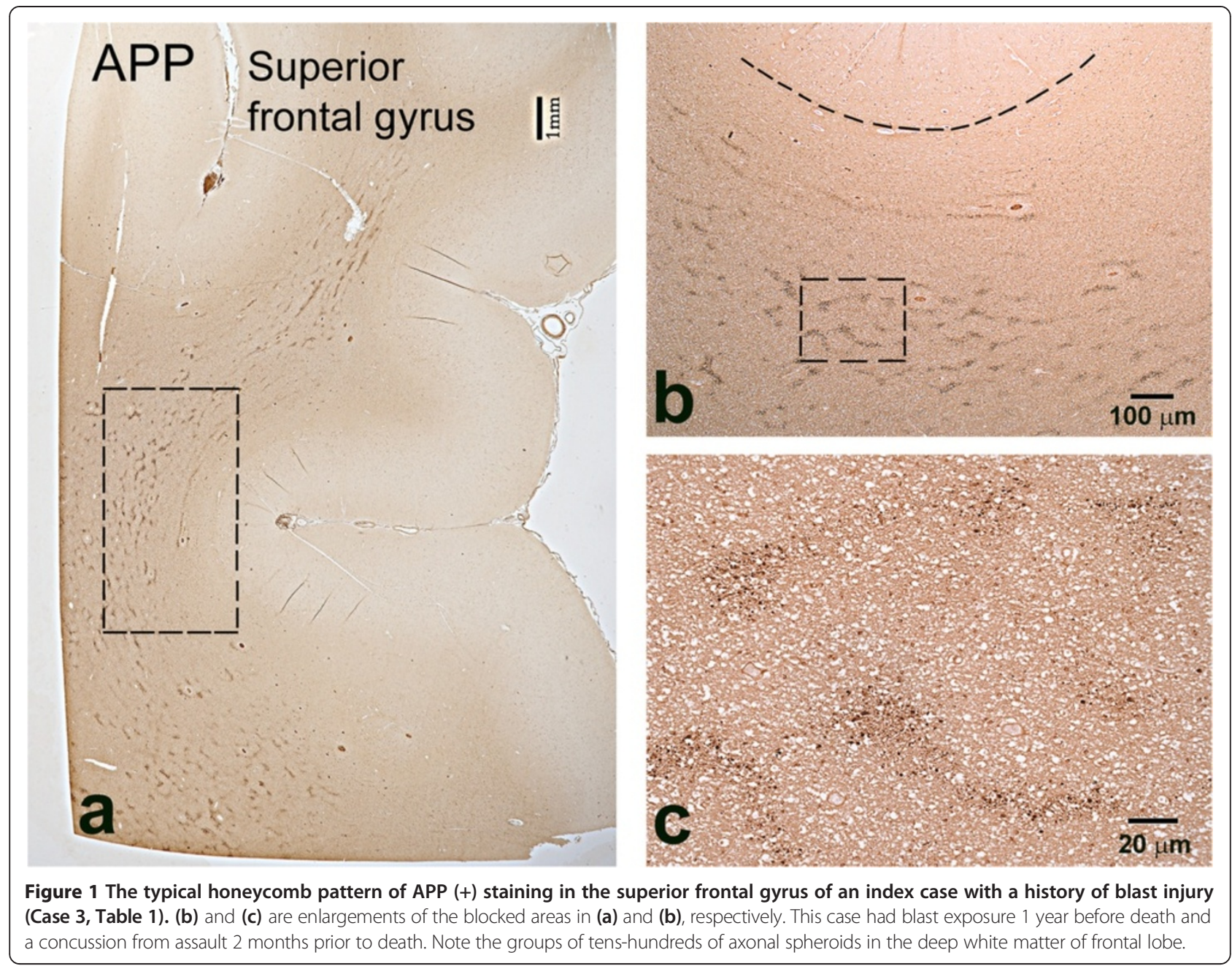

superior cerebellar peduncle, and cerebellum. In the cerebellum, axonal swellings were often seen in the deep white matter next to deep nuclei and also in the form of classical retraction balls in the granule cell layer next to Purkinje cell bodies. These retraction balls were eosinophilic, argyrophilic, and APP-immunoreactive, and were also filled with phosphorylated neurofilaments (Additional file 2: Figure S2 for Case 3). One of these cases, e.g. the one illustrated in Additional file 1: Figure S1 and Additional file 2: Figure S2, had suffered traumatic events other than blast relatively near the time of death. APP $(+)$ axonal swellings were occasionally encountered also in internal capsule, striatopallidal pencils, and thalamic striae.

The comparison of sections immunostained with APP and adjacent sections stained with Masson's trichrome in regions with honeycomb pattern of axonal lesions shows that APP (+) perivascular abnormalities are associated with arterioles, but not venules (Figure 3).
APP (+) axonal abnormalities in subjects with history of opiate overdose, anoxic-ischemic encephalopathy and non-blast TBI

Because 3 out of 4 blast cases with APP (+) axonal swellings had died of opiate overdose (Table 1), 6 additional cases with opiate overdose without blast exposure were analyzed as controls. In 5 out of 6 subjects, we observed a few APP $(+)$ axonal abnormalities in the medial frontal white matter, corpus callosum and the internal capsule (Figure 4), but these pathologies were significantly less pronounced compared to the ones in blast injury cases. In one case of an 18-year old female (Case 11) who died from mixed overdose with antidepressants and opiates, we found extensive axonal abnormalities in patches throughout the white matter of frontal cortex. Based on the mixed nature of intoxication that may be associated with regulatory APP events [27] this brain was not included in the opiate overdose group for further stereological analysis, but was illustrated in supplementary figures (Additional file 3: 

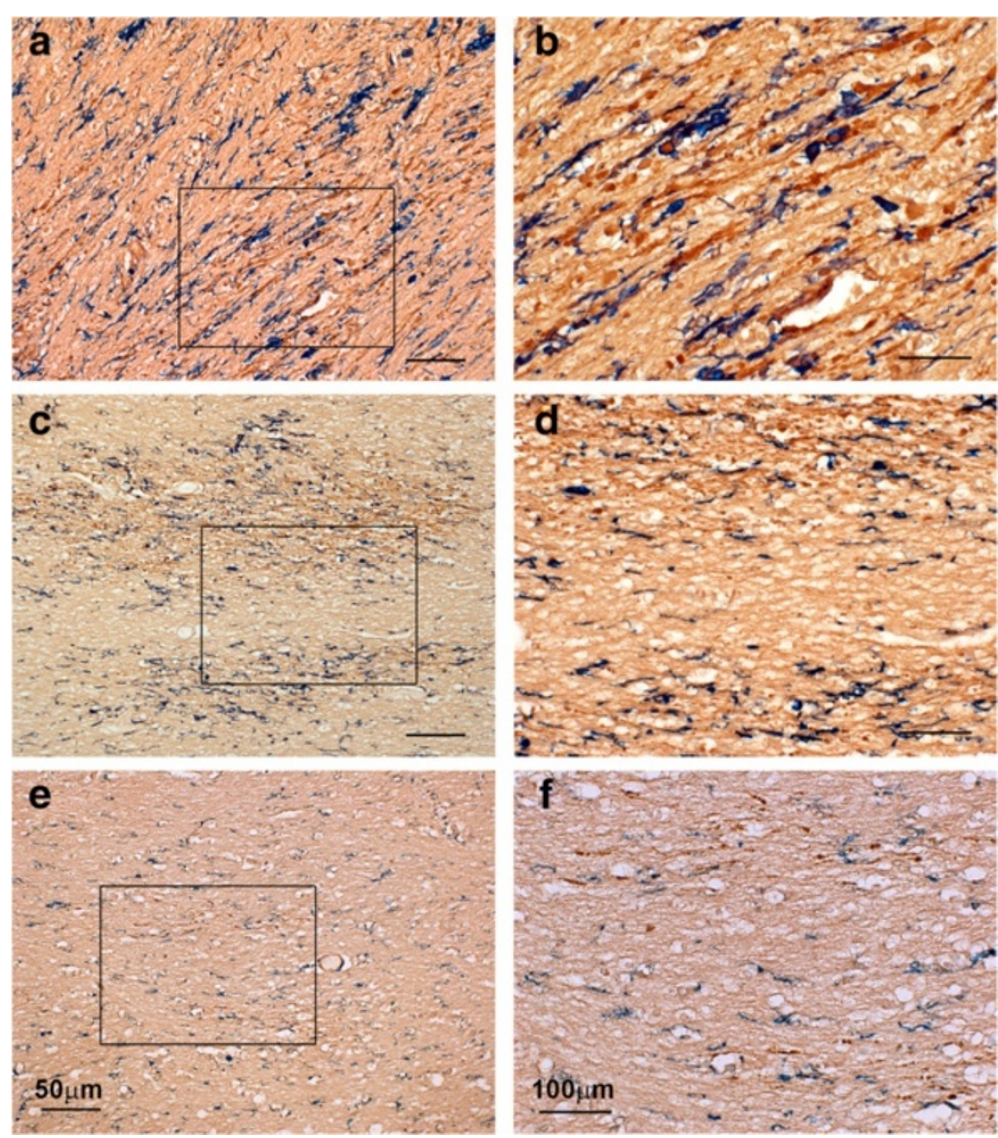

Figure 2 Sections immunostained for concomitant localization of APP and IBA1 epitopes in representative cases of MVC (Case 21; a-b), blast (Case 1; c-d), and opiate overdose (Case 7; e-f). APP (brown) and IBA1 (blue) was detected sequentially by DAB and Vector blue, respectively, as described in Methods. Note that, in MVC (a-b) and blast (c-d) APP (+) swellings and bulbs colocalise with deramified or phagocytic microglia, whereas in opiate overdose (e-f) they do not. Panels b, d, and f are magnifications of framed areas in a,c, and e, respectively. Size bars: 50 (a, c and e) and 100 (b, d, and f) $\mu \mathrm{m}$.

Figure S3). When we analyzed the density of APP (+) axonal abnormalities in frontal cortex with stereology, there were significant differences between the blast $(n=4)$ and methadone $(\mathrm{n}=4)$ groups $(\mathrm{P}=0.0195$; Figure 5$)$. The honeycomb pattern of axonal injury with perivascular distribution (Figure 1) was not evident in methadone overdose cases.

In cases with anoxic-ischemic encephalopathy, APP staining of axons was extremely variable. Two cases of young adults showed rare APP (+) fiber abnormalities in medial frontal white matter and temporal lobe or brain stem (Cases 12 and 13), whereas four other cases were negative for APP signal in frontal lobe. The brain of a 16-year old patient (Case 15) who died in the course of anesthesia and had brain edema with herniation showed dense APP (+) fibers in brain stem, cerebellar white matter, medial temporal lobe (angular bundle), and internal capsule/striatopallidal pencils, but no staining in medial frontal white matter. We also reviewed two cases with exposure to methadone overdose at ages 2 and 3 (not included in Table 1). Both had medial cortical necrosis and displayed APP (+) long fiber swellings coursing vertical to the white-gray matter border and along the longitudinal axis of the gyrus that was different from the abnormalities seen in blast and opiate overdose material.

Cases 18 and 19 with cerebral contusions demonstrated axonal pathology primarily at the border of the contusion (Additional file 4: Figure S4); none had APP (+) abnormalities in the medial frontal white matter. Cases 20 and 21 with histories of MVC showed large numbers of abnormal axons with swellings and axon bulbs cursing in multiple areas, especially in the medial frontal white matter and anterior corpus callosum, without clear association with blood vessels (Additional file 5: Figure S5 for Case 20). No evident APP (+) axonal abnormalities were seen in controls with negative neuropsychiatric histories.

As shown in Figures 6 and 7, the microscopic appearance of axonal abnormalities is different among cases with histories of motor vehicle crash (the classical scenario causing DAI) versus blast versus opiate overdose. In coronal sections like the ones used in this study, 

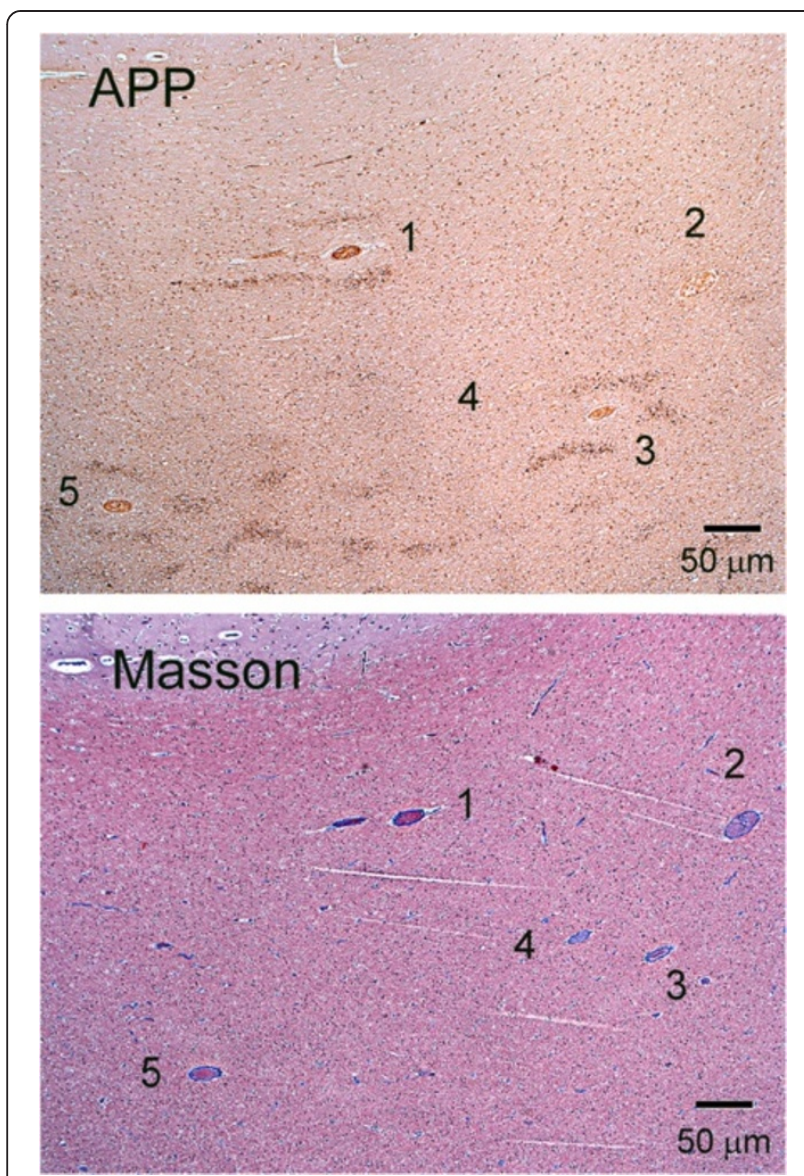

Figure 3 Perivascular distribution of APP-immunoreactive axon abnormalities demonstrated here on adjacent sections, one of which (top) was processed for APP immunohistochemistry and the other (bottom) with Masson trichrome stain (images taken from Case 3). Numbers indicate corresponding blood vessels. Note that axonal abnormalities encircle aniline blue $(+)$ thick-walled vessels representing arterioles $(\# 1,3,5)$, but not thin-walled vessels that are venules (\#2,4). (4) is not evident on top section and only its position was marked as such. Size bars: $50 \mu \mathrm{m}$.

axonal abnormalities in cases of motor vehicle crash are thick with prominent undulations and classical axon bulbs; in the case of opiate overdose, axonal abnormalities are thin and straight, with multiple varicosities in the course of a single axon; in blast cases, axonal abnormalities fall in-between classical DAI and opiate overdose cases and feature prominent varicosities and spheroids (Figure 6 and, in further magnification, Figure 7).

\section{Neuroinflammatory responses and other neuropathologies}

To explore the regional association of axonal abnormalities with neuroinflammatory responses in the brains of blast cases, we performed IHC for the microglial marker IBA1 or the astrocytic marker GFAP and compared such labeling with immunolabeling for APP on same or adjacent sections. Figure 8 shows evidence of colocalization of IBA1
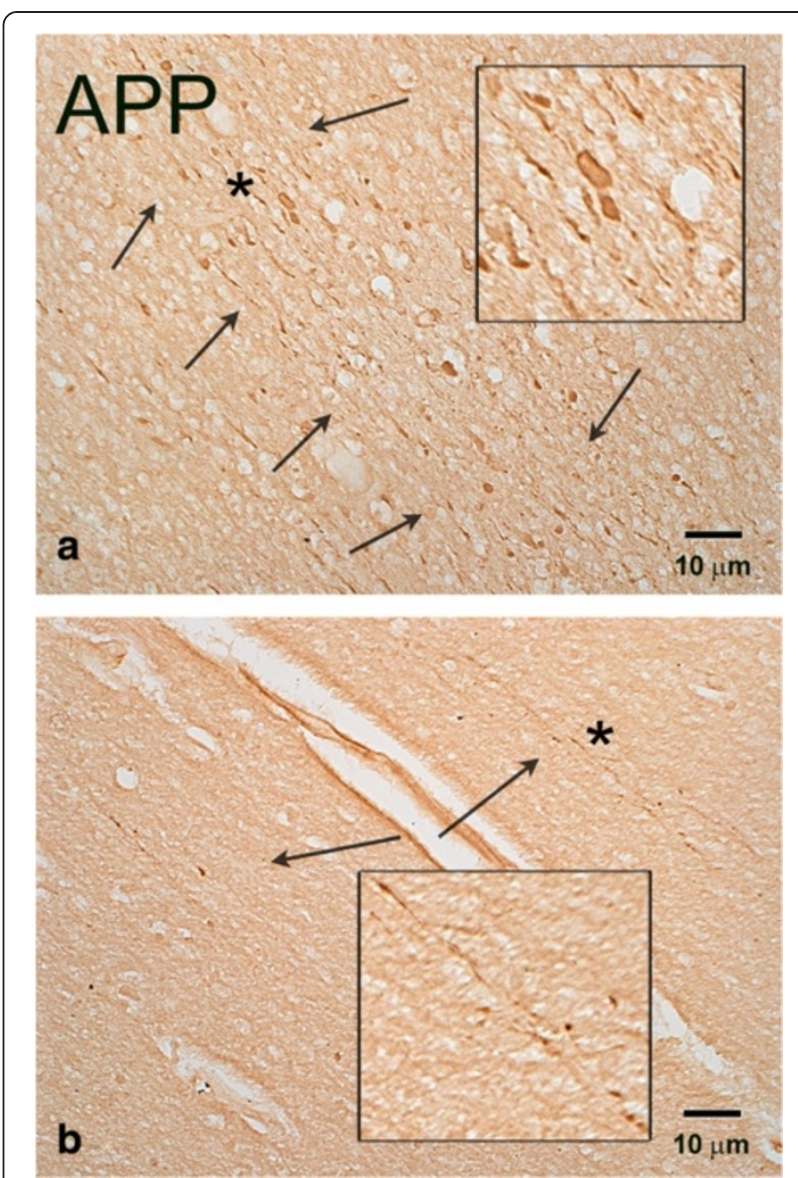

Figure 4 APP (+) axonal abnormalities in the frontal lobe of a representative patient without history of blast who died as a result of opiate overdose (Case 9, Table 1). Although there are occasional clusters of axonal swellings (arrows, a), most cases of observed abnormalities are less conspicuous (arrows, b). Insets represent magnifications of areas marked with an asterisk. Size bars: $10 \mu \mathrm{m}$.

(+) deramified/hypertrophic microglia with patches of abnormal APP $(+)$ axons in the corpus callosum of an index case with blast history (Case 1). The best evidence of colocalization of APP (+) axonal abnormalities with activated microglia in blast cases is shown in double-labeling preparations as the one illustrated in Figure 2c-d (Case 1). A similar colocalization of hypertrophic, phagocytic microglia with APP ( + ) axonal abnormalities is seen in DAI associated with MVC (Figure 2a-b; Case 21). On the other hand, there is no evidence of microglial activation next to abnormal axons in cases of opiate overdose (Figure 2e-f; Case 7). In contrast to the colocalization of APP (+) axonal abnormalities with activated microglia in blast and MVC cases, there was no clear evidence for colocalization of such abnormalities with GFAP $(+)$ reactive astrocytes.

Gross measures of hypoxia-ischemia were variable in our blast material; one out of five cases showed hippocampal CA1 degeneration, 4 cases showed apparentreduction 


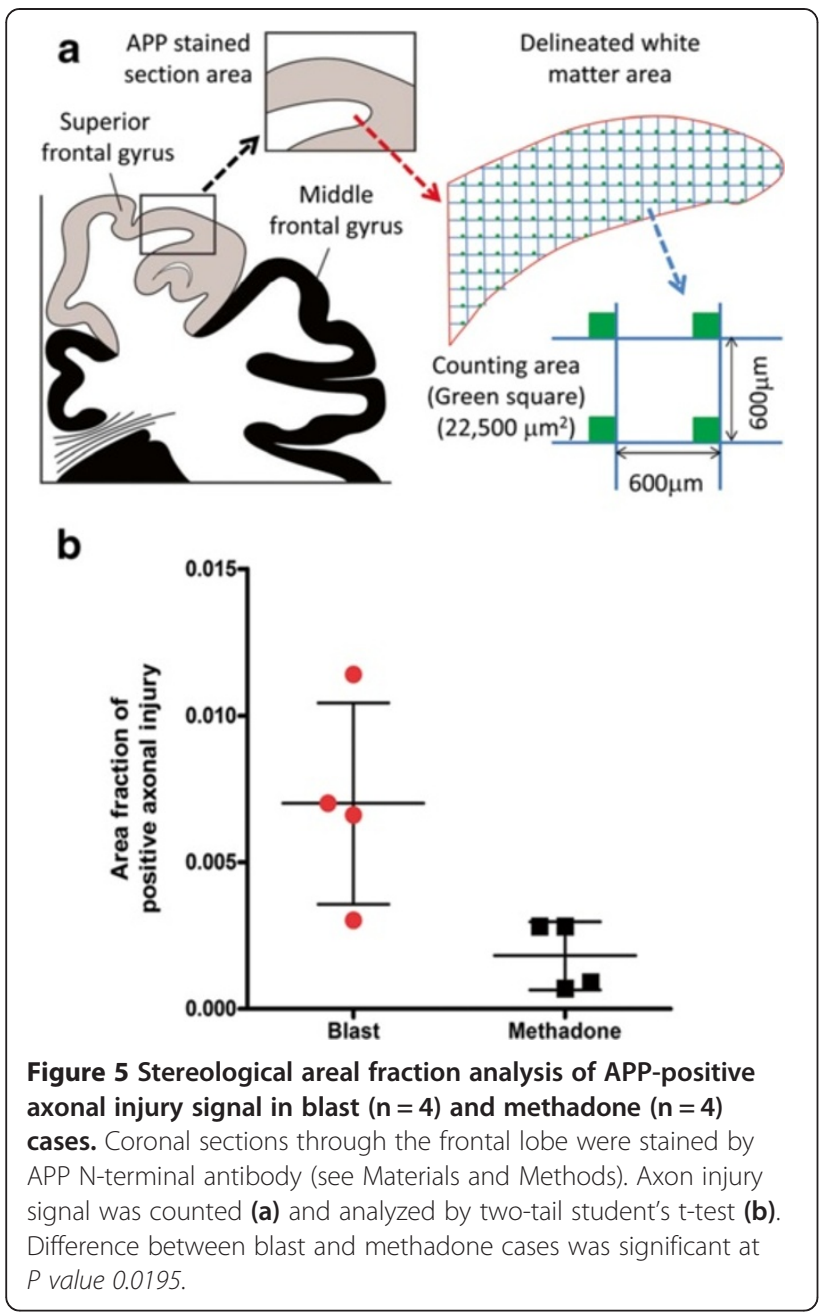

in numbers of Purkinje cells in cerebellar cortex and none showed cortical necrosis. In comparison, 4 out of 6 cases of methadone overdose showed CA1 degeneration or necrosis, 2 cases showed Purkinje cell degeneration or necrosis and 3 cases showed cortical necrosis. On the other hand, all 6 cases of hypoxic-ischemic encephalopathy showed CA1 and Purkinje cell degeneration or necrosis, 5 cases showed cortical necrosis and 4 cases showed basal ganglia necrosis (Table 1). The severity of anoxicischemic changes in these three groups of cases appears to bear no association with the severity of axonal abnormalities in the medial frontal white matter.

To explore the possibility that blast exposure is associated with tauopathy as suggested in a recent study [28], we processed sections of the frontal and temporal lobes of 5 blast cases with IHC for distinct phosphorylated and conformational tau epitopes using antibodies AT8, CP13, PHF1 and MC1. We did not detect a positive signal in any of these blast cases (Additional file 6: Figure S6), including Case 4 that survived 4 years after blast, despite the fact that all antibodies reacted with neurofibrillary tangles in control AD cases (data not shown) and all antibodies except MC1 stained tangles in an established case of dementia pugilistica (Additional file 6: Figure S6a-f).

\section{Discussion}

Relevance of findings and comparison with other lines of research

Our findings show that brains of subjects with a history of blast exposure are featured by widespread APP $(+)$ axonal abnormalities. In the cortical white matter, these abnormalities appear primarily as clusters of small axonal varicosities or spheroids. This form of DAI differs from classical DAI due to MVC or axonal degeneration associated with contusions. Although most of the brains with blast histories examined here belong to subjects who died from opiate overdose, the pathological patterns described here differ from axonal lesions in subjects that died from overdose without history of blast exposure. Differences are based on density, their degree of association with neuroinflammation, and also some microscopic features of axonal abnormalities. It is possible that prior blast or blunt TBI exposure and particular antemortem circumstances, such as opiate overdose and/or anoxia, may act in synergy to produce the honeycomb pattern of APP staining seen in Figure 1. The focus of this study was APP $(+)$ axonopathy without any claims as to whether this is a primary or secondary outcome of blast. Although traumatic axonopathy has been confirmed by several groups working on animal models of blast TBI $[10,11,29]$, some investigators place emphasis on microvascular pathology [30,31].

To our knowledge, this is the first direct evidence of DAI in the brains of veterans with prior blast exposure. Indirect evidence consistent with the presence of DAI comes from diffusion tensor imaging (DTI) studies on soldiers with blast histories. Mac Donald et al have reported abnormal DTI signal in the middle cerebellar peduncle, cingulum, and orbitofrontal white matter of U.S. military personnel within 90 days of injury [4], but only middle cerebellar peduncle abnormalities were replicated in a follow-up report focusing on pure primary blast injury [32]. In another DTI study, Jorge et al reported on regions of reduced low fractional anisotropy in the brains of OIF/OEF veterans with mild TBI. These lesions had a predilection for the corpus callosum and, less so, the cerebellum, and could be caused by axonal injury [12]. Another DTI study in veterans of OIF/OEF with histories of mild TBI showed similar patterns [33]. Yet other investigators failed to find DTIbased abnormalities in veterans with mild-to moderate blast TBI [34].

Anatomical regions highlighted in DTI studies partially overlap with the regional distribution of DAI lesions 

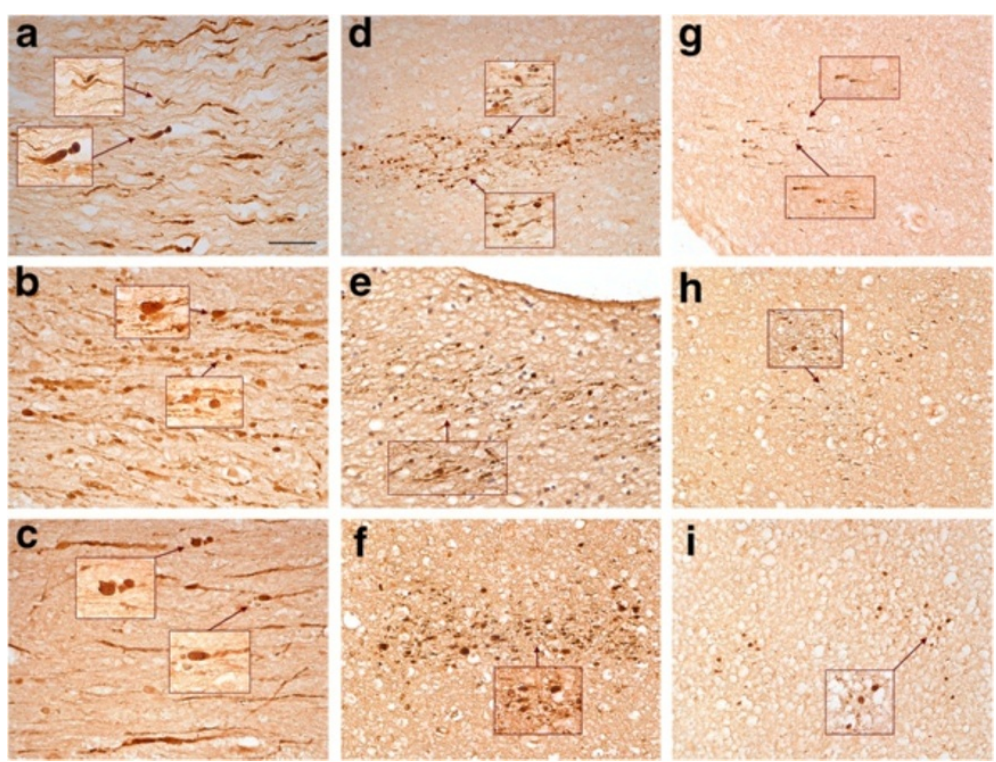

Figure 6 Microscopic features of APP (+) axon abnormalities in motor vehicle crashes (a-c), blast (d-f) and opiate overdose (g-i) in typical cases. a is taken from Case 20, $\mathbf{b}$ and $\mathbf{c}$ from Case 21, $\mathbf{d}$ from Case 4, e from Case 5, $\mathbf{f}$ from Case 3, $\mathbf{g}$ from Case $9, \mathbf{h}$ from Case 7 and $\mathbf{i}$ from Case 6. Insets represent enlargements of indicated areas. Note differences in size of axons among the three types of injury and also the prominence of undulations and axon bulbs in cases of motor vehicle crash (a-c). Portions of the insets are further magnified in Figure 7. Size bars: $50 \mu \mathrm{m}$.
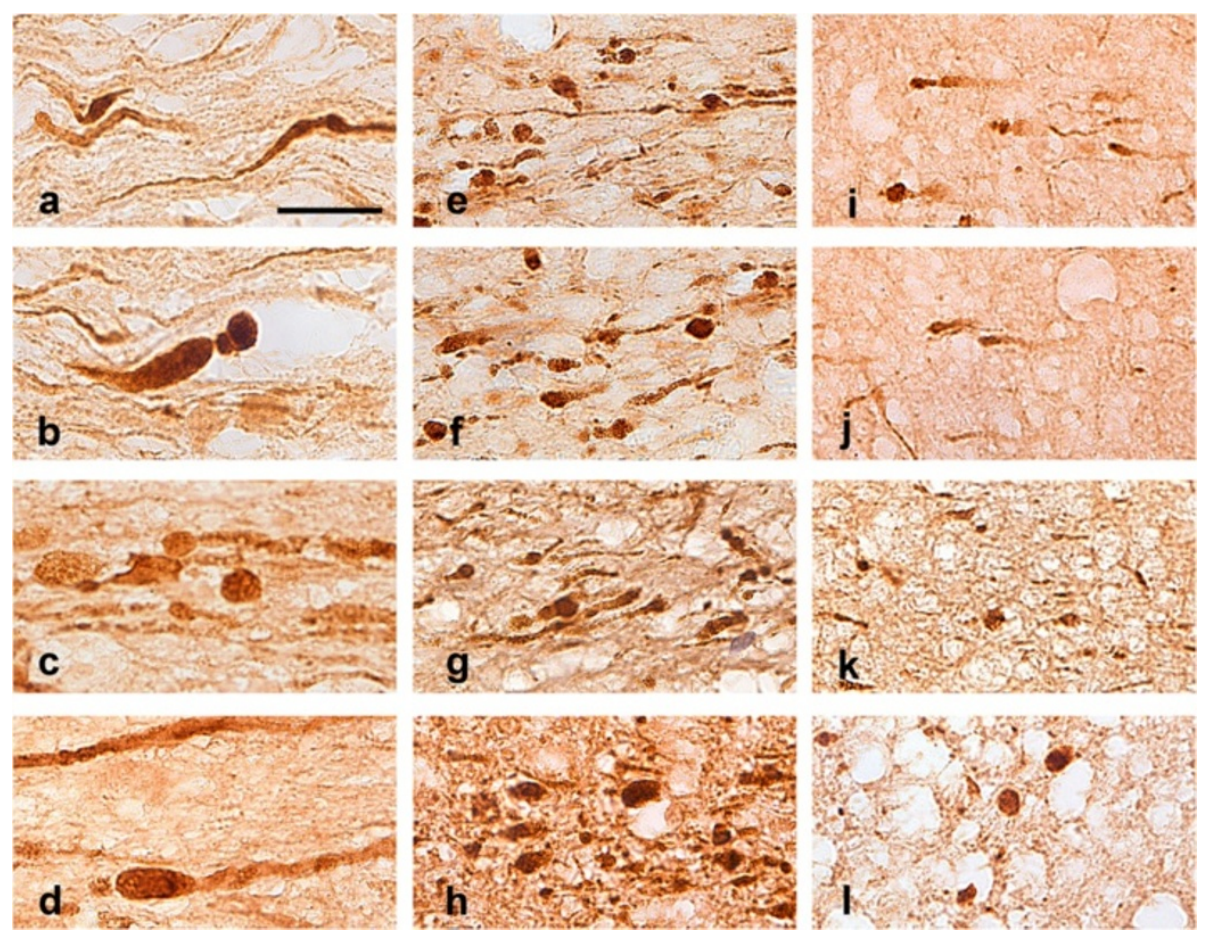

Figure 7 Further magnification of areas indicated with arrows in Figure 6. Arrangement of panels is exactly as in Figure 6. These images illustrate in greater detail the anatomical differences of injured axons among classical traumatic DAl (a and $\mathbf{b}$ from Case 20, c and $\mathbf{d}$ from Case 21), blast (e and $\mathbf{f}$ from case 4, $\mathbf{g}$ from Case 5, $\mathbf{h}$ from Case 3), and opiate overdose (i and $\mathbf{j}$ from Case 9, $\mathbf{k}$ from Case 7, I from Case 6). Size bars: 20 um. 

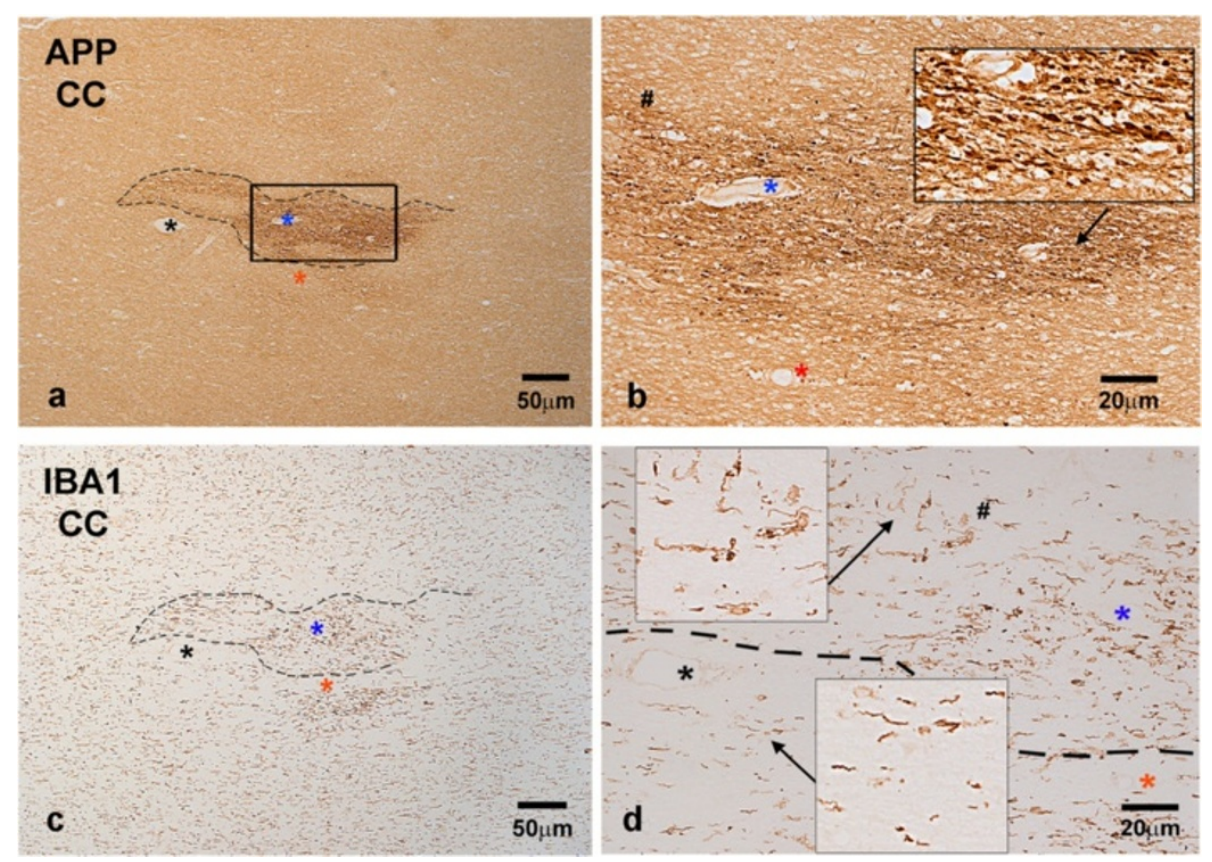

Figure 8 Adjacent sections through the anterior corpus callosum of a typical blast case (Case 1; Table 1) immunostained with an axonal injury marker (APP; a-b) and microglial marker (IBA1; c-d). b is enlargement of bracketed area in a and shows, in greater detail, abnormally swollen axons traveling in various directions. $\mathbf{d}$ is an enlargement of bracketed are in $\mathbf{c}$ taken through the border between healthy tissue and a patch of axonopathy. Insets in d are magnifications of microglial profiles indicated with arrows. Note the correspondence of axonopathy (a) with neuroinflammation (c) in the same patch of tissue and the transition between ramified and deramified/round microglia in the border between reactive and non-reactive tissue in (d). In Figure 2e-f, note that microglia has resting cytology and there are no appreciable differences between areas with APP (+) axonopathy and areas without. Size bars: 50 (a and c) and 20 (b and d) $\mu \mathrm{m}$.

reported here. Our findings may show a greater involvement of the hemispheres than the cerebellum, but our limited sampling does not allow definitive conclusions. Furthermore, it is unclear how the several mm-diameter "potholes" of limited fractional anisotropy described by Jorge et al [12] might correspond to the much smaller honeycomb islands identified in the present study. Blast injury simulation modeling reveals maximal shearing stress in a few brain sites including orbitofrontal, brain stem and frontal parasagittal regions [35] and predicts, in part, neuropathological patterns observed here. The selective vulnerability of certain long CNS tracts to primary blast is supported by recent animal studies demonstrating traumatic axonal injury in the corpus callosum, corticospinal, cerebellar, and lemniscal pathways $[10,11]$. The involvement of these tracts may be related to the distribution and intensity of shearing stress and other types of mechanical distortion in the brain, although such biomechanical factors may operate differently in the human versus rodent CNS [35]. The peri-arterioral distribution of axonal pathology in our blast cases may be due to similar factors, for example shearing stress of axons may be especially intense in the white matter enveloping the mechanically stiff arterial environment.

\section{TBI-associated DAI versus opiate-overdose axonopathy}

The majority of blast cases with APP $(+)$ axonal swellings had died of opiate overdose. Brains of patients who died of opiate overdose without history of blast exposure did show evidence of axonopathy, but some features of blast-associated axonal injury set it apart from the injury associated with opiate overdose. First, the severity of APP (+) axonopathy is greater in blast cases compared to cases with opiate overdose without blast history. Second, there is close relationship of APP $(+)$ axonal abnormalities with activated microglia in blast cases, even 4 years after the index event; this finding suggests the presence of neuroinflammation in regions with abnormal axons that takes days to evolve and may not be consistent with agonal events related to overdose as sufficient causes of blast-related axonopathy. Third, there are some microscopic differences between abnormal axons in cases of opiate overdose and cases with history of blast: the former present primarily as beaded, relatively thin axons, whereas the latter usually present as larger varicosities or spheroids. According to some studies, granular appearance of axons may represent advanced axonal degeneration with axon fragments persisting months or years after blast, in tandem with enduring neuroinflammation [36-38]. The longevity of axons or 
their fragments after lesions is not a rare phenomenon in neurobiology of disease [39] and some of the molecular mechanisms have been revealed in Wld mice [40,41]. Fourth, axonal abnormalities related to opiate overdose do not show the prominent peri-arteriolar honeycomb distribution of blast-associated axonal lesions.

Opiate overdose may contribute to the axonal abnormalities observed in blast cases. For example, primary blast injury may have caused endangerment of the axons or regional neuroinflammation that was further complicated by chronic use of opiates or by protracted agonal events associated with opiate overdose and culminated in the observed honeycomb pattern. In this scenario, honeycomb varicosities or spheroids may represent "fresh" low-grade axonopathy [42] in primed axons or in regions primed by chronic neuroinflammation, both from the original blast. Non-primary blast injury may also have contributed to the axonal abnormalities observed here, including tertiary injuries from concussions and quaternary thermal injuries. Traumatic events such as blunt concussions suffered outside the combat theater in the weeks prior to death may have also added to this pattern.

The association between opiate overdose and axonopathy has been reported before [43-45] and was largely ascribed to hypoxia. In our case series, brains with classical anoxic-ischemic encephalopathy had negligible axonal injury, a pattern consistent with previous studies [46]. Furthermore, rodents dying of methadone overdose do not show APP (+) axonal swellings (Leri, Koliatsos and Ryu, unpublished observations), despite the fact that traumatic axonal injury can be induced in a variety of rodent TBI models [11,47-51]. Of course, the absence of axonal injury in severe anoxic-ischemic encephalopathy does not preclude the presence of axonopathy in the case of prolonged milder hypoxia. At the same time, the absence of axonopathy in rodent models of opiate overdose does not preclude the occurrence of such in the course of opiate overdose in humans. Beading of axons in the absence of bulbs seen in opiate and other overdose cases may be associated with nodal or paranodal events, including swelling of mitochondria, as shown in experimental anoxic nerve injury [52]. The role of opiate overdose and/or anoxia in the evolution of honeycomb axonopathy in blast cases is also suggested by Case 2 that, although clearly exposed to blast, did not show APP $(+)$ axonopathy. This patient died from selfinflicted gunshot wound to the head that we assume caused instant death, a condition incompatible with prolonged agonal state and brain anoxia. The presence of honeycomb axonopathy in Case 1 that had died of multi-organ failure, but not opiate overdose, is also compatible with a role of anoxia in the establishment of such lesions.
We propose that blast exposure and agonal hypoxia (primarily caused by opiate overdose in our series) should be viewed as interactive or synergistic factors in the genesis of the honeycomb axonopathy observed here. It is difficult to say whether the spherical lesions represent residues of progressively degenerating axons from the original blast event or, rather, fresh low-grade lesions caused by prolonged hypoxia in axons primed at the time of the blast. Such questions address the broader problem of the cumulative effect of multiple injurious impacts to the brain and, to some extent, can be modeled and studied in animals.

\section{Blast history and tauopathy}

Two recent reports $[28,53]$ have demonstrated the presence of tauopathy in the brains of five veterans with prior blast exposure and one of these studies [28] modeled this finding on single-blast exposure of mice featuring free head movement. The same study [28] reported axonal and microglial pathology next to tau deposits that are not directly comparable to our findings. Using an identical panel of phosphorylated tau antibodies as Goldstein et al [28], we were unable to confirm tau hyperphosphorylation in any of our 5 blast subjects, including a case that had survived 4 years after blast. Neuropsychiatric symptoms in our subjects were broadly similar to these of the other reports and involved a combination of PTSD, depression and cognitive difficulties. The varied findings may be due to a number of reasons including a limited number of sampling sites in our material, differences in tissue processing such as length of fixation, and differences in average time interval between blast events and death that was somewhat longer in the case series of Goldstein et al [28]. At the very least, the issue of tauopathy after military blast history is very complex and findings from one case or case series cannot be readily generalized. As in the case of other comparisons made here, there is great need for several types of controls, including adequate sampling of young or middle-aged subjects without blast or TBI history.

\section{Clinical considerations and problems in establishing cause and effect}

Although it is risky to draw clinical conclusions based on pathological autopsy material, the strong frontal and paralimbic patterns of axonal injury reported here may shed light into the problem of chronic executive and attentional difficulties experienced by chronic survivors of blast TBI [54]. On another clinical subject, the nonintentional overdose by methadone, used as a popular analgesic by veterans, is a very important problem in retired military personnel $[55,56]$ and it is possible that it may exacerbate pre-existing axonal injuries. This important issue should be clarified with further research. 
Naturally, any study based on brain autopsy material from the complex cohort of OIF/OEF veterans should take into account a life style often featured by repeat combat and non-combat TBI and substance abuse/overdose. As highlighted in the previous sections of Discussion, these events may act in synergy to cause axonopathy. Time parameters are also important. Acute and chronic DAI have different microscopic appearances [36,38] and, at the same time, survival time also reflects TBI severity: Lethal TBI by definition involves brief survival and causes severe acute axonopathy featured by prolific axonal swellings with bulbs; mild TBI is not a cause of death per se and is naturally associated with fewer axonal lesions that fade over time or persist as granular residues. Thus, survival time may play an important role in the differences seen between DAI due to MVC and DAI in subjects with blast histories (Figures 6 and 7).

Our findings provide the groundwork for a fresh look into the problem of blast injury to brain, and stress the fact that DAI may be shared between blast and other types of acceleration injury to brain, although pathological details appear to be different. Importantly, our study underlines the complexity of cases with blast history that come to autopsy and the need to engage several different types of controls, while recognizing the possibility of interacting pathogenic factors. Simple blast cases featuring solely primary blast events without secondary, tertiary etc components and not associated with other combat or non-combat TBI or substance abuse comorbidities or antemortem hypoxia may lend themselves to more straightforward clinico-pathological analyses, but such cases are probably a small fraction of the TBI problem in the OIF/OEF veteran cohort and are extremely rarely represented in autopsy samples. While one may be tempted to establish clear cause-and-effect relationships based on simpler cases, it may be the cumulative impact of multiple pathogenic factors and morbidities that determines TBI-related outcomes in veterans of recent wars.

\section{Conclusions}

Brains of subjects with history of blast exposure show a honeycomb pattern of APP (+) axonopathy, detected here in the medial dorsal frontal white matter. Most of these subjects had died of opiate overdose. Axonal abnormalities in blast subjects are affiliated with reactive microgliosis, a pattern that distinguishes them from control cases of subjects who died of opiate overdose but had no blast history. Blast-associated axonopathy is also denser compared to that seen in opiate subjects and appears to have some distinct microscopic features. It is possible that blast and concurrent blunt TBI exposure as well as particular antemortem circumstances, such as opiate overdose and/or anoxia, may act in synergy to produce the pattern of APP axonopathy observed here. Our study establishes the background for future work that should help clarify the previous mechanisms and provide more definitive insights into the hundred-year old problem of blast neurotrauma.

\section{Additional files}

Additional file 1: Figure S1. APP $(+)$ axonopathy in the corpus callosum of an index case with history of blast injury (Case 3, Table 1). Enlarged, fusiform axons and axonal bulbs are indicated with arrows in (a). (b) represents an enlargement of the blocked area in (a). It is unclear whether these patches of classical DAl are associated with blast or, rather, the concussion suffered as a result of assault 2 months prior to death.

Additional file 2: Figure S2. Neuropathological findings in the cerebellum of an index case of blast injury (Case 3, Table 1) based on staining with hematoxylin-eosin (a), Gallyas silver (b), and phosphorylated neurofilament (c) or APP (d) immunohistochemistry. Note enlarged eosinophilic (a) or argyrophilic (b) or phosphorylated neurofilament- and APP-immunoreactive axon bulbs (c and d) in the Purkinje or granule cell layer next to the cell bodies of Purkinje cells (arrows). APP immunohistochemistry is especially sensitive in detecting these axonal abnormalities. Insets represent magnifications of areas indicated with asterisks. As in the case of classical axonal swellings with bulbs in Additional file 1: Figure S1, it is unclear whether these profiles are associated with blast or the concussion suffered from assault 2 months before death. GL, glomerular cell layer; ML, molecular layer; PCL, Purkinje cell layer. Size bars: $5 \mu \mathrm{m}$ (a) and $20 \mu \mathrm{m}$ (b, c and d).

Additional file 3: Figure S3. This case of mixed drug overdose (Case 11 in Table 1), including opiates, is associated with severe axonal injury that serves to illustrate better the type of axonopathy that occurs in drug intoxication. Although the pattern is qualitatively similar to that in opiate overdose, the intensity of labeling is unusually high. Note the straight thin axons with periodic round swellings (arrows in b). Size bars: $50 \mu \mathrm{m}$.

Additional file 4: Figure S4. Patterns of APP $(+)$ axonal pathology in brain contusions. Case illustrated here (Case 19, Table 1) had hemorrhagic contusion in ventromedial frontal lobe (a, arrows). Note the presence of multiple APP (+) dilated, short axon stumps (circles) in the periphery of hemorrhage (area indicated with an asterisk in a). Size bars: 500 (a) and 20 (b) $\mu \mathrm{m}$.

Additional file 5: Figure S5. APP (+) axonal pathology in cases of motor vehicle crashes is especially dense in medial dorsal frontal lobe (a, arrows). Images here correspond to case 20 (Table 1). Axonal abnormalities do not display perivascular patterns as in the case of blast injuries ( $b$; this is an enlargement of framed area in a). Size bars: $1 \mathrm{~mm}$ (a) and $25 \mu \mathrm{m}$ (b).

Additional file 6: Figure S6. Phosphorylated tau (AT8, CP13 and PHF1) staining of three blast injury cases ( $g, h$ and i) compared with an established dementia pugilistica case used here as positive control (a to f). Although antibodies AT8, CP13 and PHF1 react intensely with phosphorylated tau epitopes in the of the dementia pugilistica case (a-c; $d$-f are magnifications of framed areas in $a-c$, respectively), no immunoreactivity is seen in the hippocampus of Case 5 with history of blast exposure ( $g$-i). Sections through the temporal lobe of other blast cases were similarly negative and MC1 antibody did not stain brain tissues with a history of dementia pugilistica or blast (data not shown). Size bars: $2 \mathrm{~mm}(\mathrm{a}, \mathrm{b}, \mathrm{c}, \mathrm{g}, \mathrm{h}$, and i) and $50 \mu \mathrm{m}$ (d, e, and $f$.

\section{Abbreviations}

AD: Alzheimer's disease; AFIP: Armed Forces Institute of Pathology; APP: Amyloid precursor protein; BRC: Johns Hopkins Brain Resource Center; CNS: central nervous system; DAB: diaminobenzidine; DAl: Diffuse axonal injury; DTI: Diffusion tensor imaging; GFAP: Glial fibrillary acidic protein; IBA1: Ionized calcium-binding adapter molecule 1; IHC: Immunohistochemistry; MVC: motor vehicle crash; OEF: Operation Enduring Freedom; OIF: Operation Iraqi Freedom; PTSD: post traumatic stress disorder; TBI: Traumatic brain injury. 


\section{Competing interests}

The authors declare that they have no competing interests.

\section{Authors' contributions}

$J R$, LX and VEK designed the experimental approach. JR performed most of the experiments including stereology and also contributed to writing of the manuscript. LX performed Tau immunohistochemistry. OP and IHS collected and prepared human brain tissues and procured medical histories. JT and CE characterized general neuropathology in our samples. FL performed animal experiments of great interpretative value to the manuscript. VEK coordinated the project and wrote the manuscript. All authors read and approved the final manuscript.

\section{Authors' information}

$J R$ is a Research Specialist in the Department of Pathology, Division of Neuropathology, at Johns Hopkins University School of Medicine. IHS is a Pathologist in the Department of Neuropathology and Ophthalmic Pathology, Joint Pathology Center (formerly the Armed Forces Institute of Pathology, AFIP), Defense Health Agency. LX is a Research Associate in the Department of Pathology, Division of Neuropathology, at Johns Hopkins University School of Medicine. OP is a Research Associate in the Department of Pathology and Manager of the Brain Resource Center at Johns Hopkins University School of Medicine. FL is a Professor in the Department of Psychology, University of Guelph, Ontario, Canada. CE is a Professor of Pathology and Ophthalmology and the Director of the Divisions of Neuropathology and Ophthalmic Pathology at Johns Hopkins University School of Medicine. JCT directs the Brain Resource Center of Johns Hopkins University. VEK is a Professor of Pathology and Neurology and Associate Professor of Psychiatry and Behavioral Sciences at Johns Hopkins University School of Medicine.

\section{Acknowledgements}

This work was supported from the Johns Hopkins Alzheimer's Disease Research Center grant RFA AG-09-001 and generous gifts from the Kate Sidran Family Foundation and Sam and Sheila Giller family. The antibodies against phosphorylated tau; PHF1, CP13 and MC1, were generous gift from Dr. Peter Davies (Albert Einstein College of Medicine, Bronx, NY).

\section{Author details}

${ }^{1}$ Department of Pathology, Division of Neuropathology, Johns Hopkins University School of Medicine, Baltimore, MD 21205, USA. ²Department of Neuropathology \& Ophthalmic Pathology, Joint Pathology Center, Defense Health Agency, 606 Stephen Sitter Ave., Silver Spring, MD 20910, USA. ${ }^{3}$ Department of Neurology, Johns Hopkins University School of Medicine, Baltimore, MD 21205, USA. ${ }^{4}$ Department of Psychiatry and Behavioral Sciences, Johns Hopkins University School of Medicine, Baltimore, MD 21205, USA. ${ }^{5}$ Department of Psychology, University of Guelph, Guelph, ON N1G 2 W1, Canada.

\section{Received: 4 October 2014 Accepted: 11 October 2014} Published online: 25 November 2014

\section{References}

1. Mott FW (1916) The effects of high explosives upon the central nervous system. Lancet 1:331-338, doi:10.1016/S0140-6736(00)52963-8

2. Department of Defense (2012) DoD Worldwide Numbers for Traumatic Brain Injury. http://dvbic.dcoe.mil/dod-worldwide-numbers-tbi

3. Cernak I, Noble-Haeusslein $\sqcup$ (2010) Traumatic brain injury: an overview of pathobiology with emphasis on military populations. J Cereb Blood Flow Metab 30:255-266, doi:10.1038/jcbfm.2009.203

4. Mac Donald CL, Johnson AM, Cooper D, Nelson EC, Werner NJ, Shimony JS, Snyder AZ, Raichle ME, Witherow JR, Fang R, Flaherty SF, Brody DL (2011) Detection of blast-related traumatic brain injury in U.S. military personnel. N Engl J Med 364:2091-2100, doi:10.1056/NEJMoa1008069

5. Miller KJ, Ivins BJ, Schwab KA (2013) Self-Reported Mild TBI and Postconcussive Symptoms in a Peacetime Active Duty Military Population: Effect of Multiple TBI History Versus Single Mild TBI. J Head Trauma Rehabil 28:31-38, doi:10.1097/HTR.0b013e318255ceae

6. Gironda RJ, Clark ME, Ruff RL, Chait S, Craine M, Walker R, Scholten J (2009) Traumatic Brain Injury, Polytrauma, and Pain: Challenges and Treatment
Strategies for the Polytrauma Rehabilitation. Rehabil Psychol 54:247-258, doi:10.1037/a0016906

7. Lew HL, Otis JD, Tun C, Kerns RD, Clark ME, Cifu DX (2009) Prevalence of chronic pain, posttraumatic stress disorder, and persistent postconcussive symptoms in OIF/OEF veterans: Polytrauma clinical triad. J Rehabil Res Dev 46:697-702, doi:10.1682/JRRD.2009.01.0006

8. Taylor BC, Hagel EM, Carlson KF, Cifu DX, Cutting A, Bidelspach DE, Sayer NA (2012) Prevalence and Costs of Co-occurring Traumatic Brain Injury With and Without Psychiatric Disturbance and Pain Among Afghanistan and Iraq War Veteran VA Users. Med Care 50:342-346, doi:10.1097/MLR.0b013e318245a558

9. Shively SB, Perl DP (2012) Traumatic brain injury, shell shock, and posttraumatic stress disorder in the military-past, present, and future. J Head Trauma Rehabil 27:234-239, doi:10.1097/HTR.0b013e318250e9dd

10. De Lanerolle NC, Bandak F, Kang D, Li AY, Du F, Swauger P, Parks S, Ling G Kim JH (2011) Characteristics of an explosive blast-induced brain injury in an experimental model. J Neuropathol Exp Neurol 70:1046-1057, doi:10.1097/NEN.0b013e318235bef2

11. Koliatsos VE, Cernak I, Xu L, Song Y, Savonenko A, Crain BJ, Eberhart CG, Frangakis CE, Melnikova T, Kim H, Lee D (2011) A mouse model of blast injury to brain: initial pathological, neuropathological, and behavioral characterization. J Neuropathol Exp Neurol 70:399-416, doi:10.1097/NEN.0b013e3182189f06

12. Jorge RE, Acion L, White T, Tordesillas-Gutierrez D, Pierson R, Crespo-Facorro B, Magnotta VA (2012) White matter abnormalities in veterans with mild traumatic brain injury. Am J Psychiatry 169:1284-1291, doi:10.1176/appi.ajp.2012.12050600

13. Adams JH, Graham DI, Murray LS, Scott G (1982) Diffuse axonal injury due to nonmissile head injury in humans: an analysis of 45 cases. Ann Neurol 12:557-563, doi:10.1002/ana.410120610

14. Blumbergs PC, Jones NR, North JB (1989) Diffuse axonal injury in head trauma. J Neurol Neurosurg Psychiatry 52:838-841, doi:10.1136/jnnp.52.7.838

15. Blumbergs PC, Scott G, Manavis J, Wainwright H, Simpson DA, Mclean AJ (1994) Staining of Amyloid Precursor Protein to Study Axonal Damage in Mild Head-Injury. Lancet 344:1055-1056, doi:10.1016/S0140-6736(94)91712-4

16. Mittl RL, Grossman Rl, Hiehle JF, Hurst RW, Kauder DR, Gennarelli TA, Alburger GW (1994) Prevalence of MR evidence of diffuse axonal injury in patients with mild head injury and normal head CT findings. AJNR Am J Neuroradiol 15:1583-1589, http://www.ncbi.nlm.nih.gov/pubmed/7985582

17. Strich SJ (1956) Diffuse degeneration of the cerebral white matter in severe dementia following head injury. J Neurol Neurosurg Psychiatry 19:163-185, doi:10.1136/jnnp.19.3.163

18. Smith DH, Meaney DF, Shull WH (2003) Diffuse axonal injury in head trauma. J Head Trauma Rehabil 18:307-316, doi:10.1097/00001199-200307000-00003

19. Povlishock JT (1992) Traumatically Induced Axonal Injury - Pathogenesis and Pathobiological Implications. Brain Pathol 2:1-12

20. Povlishock JT, Christman CW (1995) The Pathobiology of Traumatically Induced Axonal Injury in Animals and Humans - A Review of Current Thoughts. J Neurotrauma 12:555-564, doi:10.1089/neu.1995.12.555

21. Strich S (1961) Shearing of nerve fiberes as a cause of brain damage due to head injury: A Pathological Study of Twenty Cases. The Lancet 278:443-448, doi:10.1016/S0140-6736(61)92426-6

22. Blumbergs PC, Scott G, Manavis J, Wainwright H, Simpson DA (1995) Topography of Axonal Injury As Defined by Amyloid Precursor Protein and the Sector Scoring Method in Mild and Severe Closed-Head Injury. J Neurotrauma 12:565-572, doi:10.1089/neu.1995.12.565

23. Chen XH, Johnson VE, Uryu K, Trojanowski JQ, Smith DH (2009) A Lack of Amyloid beta Plaques Despite Persistent Accumulation of Amyloid beta in Axons of Long-Term Survivors of Traumatic Brain Injury. Brain Pathol 19:214-223, doi:10.1111/j.1750-3639.2008.00176.x

24. Gentleman SM, Nash MJ, Sweeting CJ, Graham DI, Roberts GW (1993) Beta-Amyloid Precursor Protein (Beta-App) As A Marker for Axonal Injury After Head-Injury. Neurosci Lett 160:139-144, doi:10.1016/0304-3940(93) 90398-5

25. Hedreen JC, Koliatsos VE (1994) Phosphorylated neurofilaments in neuronal perikary perikarya and dendrites in human brain following axonal damage. J Neuropathol Exp Neurol 53:663-671, doi:10.1097/NEN

26. Gundersen HJG, Bendtsen TF, Korbo L, Marcussen N, Moller A, Nielsen K, Nyengaard JR, Pakkenberg B, Sorensen FB, Vesterby A, West MJ (1988) Some new, simple and efficient stereological methods and their use in pathological research and diagnosis. APMIS 96:379-394, doi:10.1111/j.1699-0463.1988. tb05320.x 
27. Pakaski M, Bjelik A, Hugyecz M, Kasa P, Janka Z, Kalman J (2005) Imipramine and citalopram facilitate amyloid precursor protein secretion in vitro. Neurochem Int 47:190-195, doi:10.1016/j.neuint.2005.03.004

28. Goldstein LE, Fisher AM, Tagge CA, Zhang XL, Velisek L, Sullivan JA, Upreti C, Kracht JM, Ericsson M, Wojnarowicz MW, Goletiani CJ, Maglakelidze GM, Casey N, Moncaster JA, Minaeva O, Moir RD, Nowinski CJ, Stern RA, Cantu RC, Geiling J, Blusztajn JK, Wolozin BL, Ikezu T, Stein TD, Budson AE, Kowall NW, Chargin D, Sharon A, Saman S, Hall GF, et al. (2012) Chronic traumatic encephalopathy in blast-exposed military veterans and a blast neurotrauma mouse model. Sci Transl Med 4:134-60, doi:10.1126/scitranslmed.3003716

29. Long JB, Bentley TL, Wessner KA, Cerone C, Sweeney S, Bauman RA (2009) Blast overpressure in rats: recreating a battlefield injury in the laboratory. J Neurotrauma 26:827-840, doi:10.1089/neu.2008.0748

30. Gama Sosa MA, De GR, Janssen PL, Yuk FJ, Anazodo PC, Pricop PE, Paulino AJ, Wicinski B, Shaughness MC, Maudlin-Jeronimo E, Hall AA, Dickstein DL, McCarron RM, Chavko M, Hof PR, Ahlers ST, Elder GA (2014) Selective vulnerability of the cerebral vasculature to blast injury in a rat model of mild traumatic brain injury. Acta Neuropathol Commun 2:67, doi:10.1186/2051-5960-2-67

31. Sosa MA, De GR, Paulino AJ, Pricop PE, Shaughness MC, Maudlin-Jeronimo E, Hall AA, Janssen WG, Yuk FJ, Dorr NP, Dickstein DL, McCarron RM, Chavko M, Hof PR, Ahlers ST, Elder GA (2013) Blast overpressure induces shear-related injuries in the brain of rats exposed to a mild traumatic brain injury. Acta Neuropathol Commun 1:51, doi:10.1186/2051-5960-1-51

32. Mac DC, Johnson A, Cooper D, Malone T, Sorrell J, Shimony J, Parsons M, Snyder A, Raichle M, Fang R, Flaherty S, Russell M, Brody DL (2013) Cerebellar White Matter Abnormalities following Primary Blast Injury in US Military Personnel. PLoS One 8:e55823, doi:10.1371/journal.pone.0055823

33. Morey RA, Haswell CC, Selgrade ES, Massoglia D, Liu C, Weiner J, Marx CE, Cernak I, McCarthy G (2013) Effects of chronic mild traumatic brain injury on white matter integrity in Iraq and Afghanistan war veterans. Hum Brain Mapp 34:2986-2999, doi:10.1002/hbm.22117

34. Levin HS, Wilde E, Troyanskaya M, Petersen NJ, Scheibel R, Newsome M, Radaideh M, Wu T, Yallampalli R, Chu Z, Li X (2010) Diffusion tensor imaging of mild to moderate blast-related traumatic brain injury and its sequelae. J Neurotrauma 27:683-694, doi:10.1089/neu.2009.1073

35. Taylor PA, Ford CC (2009) Simulation of blast-induced early-time intracranial wave physics leading to traumatic brain injury. J Biomech Eng 131:061007, doi:10.1115/1.3118765

36. Geddes JF, Vowles GH, Beer TW, Ellison DW (1997) The diagnosis of diffuse axonal injury: implications for forensic practice. Neuropathol Appl Neurobiol 23:339-347, doi:10.1111/j.1365-2990.1997.tb01305.x

37. Johnson VE, Stewart JE, Begbie FD, Trojanowski JQ, Smith DH, Stewart W (2013) Inflammation and white matter degeneration persist for years after a single traumatic brain injury. Brain 136:28-42, doi:10.1093/brain/aws322

38. Oehmichen M, Meissner C, Schmidt V, Pedal I, Konig HG, Saternus KS (1998) Axonal injury-a diagnostic tool in forensic neuropathology? A review. Forensic Sci Int 95:67-83, doi:10.1016/S0379-0738(98)00075-9

39. Griffin JW, George EB, Hsieh ST, Glass JD (1995) Axonal degeneration and disorders of the axonal cytoskeleton. Oxford University Press, Oxford, pp 375-390, doi:10.1093/acprof:oso/9780195082937.003.0020

40. Glass JD, Brushart TM, George EB, Griffin JW (1993) Prolonged survival of transected nerve fibres in C57BL/Ola mice is an intrinsic characteristic of the axon. J Neurocytol 22:311-321, doi:10.1007/BF01195555

41. Lunn ER, Perry VH, Brown MC, Rosen H, Gordon S (1989) Absence of Wallerian Degeneration does not Hinder Regeneration in Peripheral Nerve. Eur J Neurosci 1:27-33, doi:10.1111/j.1460-9568.1989.tb00771.x

42. Chen XH, Meaney DF, Xu BN, Nonaka M, Mclntosh TK, Wolf JA, Saatman KE, Smith DH (1999) Evolution of neurofilament subtype accumulation in axons following diffuse brain injury in the pig. J Neuropathol Exp Neurol 58:588-596, http://www.ncbi.nlm.nih.gov/pubmed/10374749

43. Buttner A (2011) Review: The neuropathology of drug abuse. Neuropathol Appl Neurobiol 37:118-134, doi:10.1111/j.1365-2990.2010.01131.x

44. Buttner A, Rohrmoser K, Mall G, Penning R, Weis S (2006) Widespread axonal damage in the brain of drug abusers as evidenced by accumulation of beta-amyloid precursor protein (beta-APP): an immunohistochemical investigation. Addiction 101:1339-1346, doi:10.1111/j.1360-0443.2006.01505.x

45. Niess C, Grauel U, Toennes SW, Bratzke H (2002) Incidence of axonal injury in human brain tissue. Acta Neuropathol 104:79-84, doi:10.1007/s00401-0020525-9
46. Dolinak D, Smith C, Graham DI (2000) Global hypoxia per se is an unusual cause of axonal injury. Acta Neuropathol 100:553-560, doi:10.1007/ s004010000218

47. Foda MA, Marmarou A (1994) A new model of diffuse brain injury in rats. Part II: Morphological characterization. J Neurosurg 80:301-313, doi:10.3171/jns.1994.80.2.0301

48. McIntosh TK, Vink R, Noble L, Yamakami I, Fernyak S, Soares H, Faden AL (1989) Traumatic Brain Injury in the Rat - Characterization of A Lateral FluidPercussion Model. Neuroscience 28:233-244, doi:10.1016/0306-4522(89) 90247-9

49. Morales DM, Marklund N, Lebold D, Thompson HJ, Pitkanen A, Maxwell WL, Longhi L, Laurer H, Maegele M, Neugebauer E, Graham DI, Stocchetti N, McIntosh TK (2005) Experimental models of traumatic brain injury: Do we really need to build a better mousetrap? Neuroscience 136:971-989, doi:10.1016/j.neuroscience.2005.08.030

50. Povlishock JT, Marmarou A, Mclntosh T, Trojanowski JQ, Moroi J (1997) Impact acceleration injury in the rat: Evidence for focal axolemmal change and related neurofilament sidearm alteration. Journal of Neuropathology and Experimental Neurology 56:347-359, AN: 00005072-199704000-00003

51. Wang HC, Ma YB (2010) Experimental models of traumatic axonal injury. J Clin Neurosci 17:157-162, doi:10.1016/j.jocn.2009.07.099

52. Waxman SG, Black JA, Stys PK, Ransom BR (1992) Ultrastructural concomitants of anoxic injury and early post-anoxic recovery in rat optic nerve. Brain Res 574:105-119, doi:10.1016/0006-8993(92)90806-K

53. Omalu B, Hammers JL, Bailes J, Hamilton RL, Kamboh MI, Webster G, Fitzsimmons RP (2011) Chronic traumatic encephalopathy in an Iraqi war veteran with posttraumatic stress disorder who committed suicide. Neurosurg Focus 31:E3, doi:10.3171/2011.9.FOCUS11178

54. Kontos AP, Kotwal RS, Elbin RJ, Lutz RH, Forsten RD, Benson PJ, Guskiewicz KM (2013) Residual effects of combat-related mild traumatic brain injury. J Neurotrauma 30:680-686, doi:10.1089/neu.2012.2506

55. Engel M (2007) Parents blame VA in fatal overdose. http://articles.latimes. com/2007/mar/12/local/me-vet12

56. Zoroya G (2008) Troops reportedly popping more painkillers. USA Today, October $20^{\text {th }}$, http://usatoday30.usatoday.com/news/military/2008-10-20paindrugs_N.htm?

\section{Submit your next manuscript to BioMed Central and take full advantage of:}

- Convenient online submission

- Thorough peer review

- No space constraints or color figure charges

- Immediate publication on acceptance

- Inclusion in PubMed, CAS, Scopus and Google Scholar

- Research which is freely available for redistribution 